\title{
The Effect of Quality Service Towards Outpatients Satisfaction at Poasia Community Health Centre
}

Adryan Fristiohady $\mathbf{1}^{*}$ (D)
La Ode Muhammad Fitrawan ${ }^{1}$
Yusniati Dwi Pemudi ${ }^{1}$
Ruslin 10
Sunandar Ihsan 10
Ruslan ${ }^{2}$
La Ode Muhammad Julian
Purnama 10
1Department of Pharmacy, Universitas
Halu Oleo, Kendari, Southeast Sulawesi,
Indonesia
2Department of Mathematics,
Universitas Halu Oleo, Kendari,
Southeast Sulawesi, Indonesia
*email: adryanfristiohady@uho.ac.id
Keywords:
Gap
Patient satisfaction
Service quality

\begin{abstract}
The quality of outpatient services can be measured by the SERVQUAL model that considers five dimensions: tangibles, reliability, responsiveness, assurance, and empathy. This study aimed to look at the effect of service quality on outpatient satisfaction at the Poasia community health center's pharmacy. The subjects in this study were 33 outpatients. The analysis technique used is gap analysis to compare patients' expectations and reality, normality test data based on questionnaire patient satisfaction tested for validation. This study's results indicate the average value of the gap in the Poasia community health center's pharmacy, amounting to -0.44 . From the value of the gap, the lowest gap value in the pharmacy center of Poasia is the place of service and the provision of inadequate drug information of -0.88 . Based on the paired t-test where a significant value $>0.05$, Ho is rejected, and Ha accepted, which means a significant difference between the quality of service and patients' satisfaction in the Pharmacy of Puskesmas Poasia Kendari City. This study concludes that there is a significant gap between expectations and reality at the Poasia community health center's pharmacy.
\end{abstract}

Received: August 28, 2020

Accepted: October $30^{\text {th }}, 2020$

Published: November 30th, 2020

(c) 2020 Adryan Fristiohady, La Ode Muhammad Fitrawan, Yusniati Dwi Pemudi, Ruslin, Sunandar Ihsan, Ruslan, La Ode Muhammad Julian Purnama. Published by Institute for Research and Community Services Universitas Muhammadiyah Palangkaraya. This is an Open Access article under the CC-BY-SA License (http://creativecommons.org/licenses/by-sa/4.0/). DOI: https://doi.org/10.33084/bjop.v3i4.1611

\section{INTRODUCTION}

Nowadays, health problems have become a basic need for the community. As the standard of living of the community increases, so does the community demand health quality (Kumar \& Preetha, 2012; Krieger \& Higgins, 2002). They require health service providers such as community health centers or Puskesmas to improve the quality of services better, not only services that are healing diseases but also include services that are preventive (preventive) to improve quality of life and provide satisfaction for consumers as users of health services (Wendimagegn \& Bezuidenhout, 2019; Kuntoro \& Istiono, 2017; Mayberry et al., 2006).
Pharmaceutical service standards are the criteria used as a guide for pharmaceutical personnel in carrying out pharmaceutical services (Bobbins et al., 2020). Pharmaceutical services are direct and responsible services to patients relating to pharmaceutical preparations to achieve definite results to improve patients' quality of life (Ministry of Health of the Republic of Indonesia, 2016). Pharmaceutical services of the community health center are an inseparable part of the organization of health efforts, which play an essential role in improving the community's quality of health services. It must support the community health center's three main functions, namely as a center for promoting health- 
oriented development, a center for community empowerment, and a first-level health service center that includes individual health services and community health services (Anderson \& Sharma, 2020; MartínezMardones et al., 2020; Herman \& Susyanty, 2012). Pharmaceutical services are integrated activities to identify, prevent, and resolve drug problems and health (Ministry of Health of the Republic of Indonesia, 2016).

Providing the highest quality service is not easy for the community health center because it involves patients' quality of life so that if an error occurs in medical treatment can harm patients (Mitchell, 2008). Lewis and Booms (1983) define quality or service quality as a measure of how well the level of service provided is consumer expectations. Based on this definition, service quality can be realized by meeting patients' needs and desires and their delivery accuracy to offset patients' expectations. Thus, two main factors affect the quality of service, namely expected services and perceived/perceived services (Widayati et al., 2017; Nadi et al., 2016).

Several dimensions are used to see patient satisfaction at the pharmacy: responsiveness, reliability, empathy, tangible, and assurance (Chusna et al., 2018). The dimension of responsiveness or responsiveness is the staff's ability to help customers and provide services responsively. Reliability is the ability to provide the promised service with immediate, accurate, and satisfactory; empathy or concern is the ease of conducting relationships, good communication, personal attention, and understanding of its customers' needs. The assurance is secured covering ability, courtesy, and trustworthiness owned by staff, is free of risk or doubt; tangibles or physical evidence is a direct manifestation which includes physical facilities, which include the expertise of the equipment used, the condition of the facilities, the condition of human resources (human resources) including the appearance of health teams and the community health center's staffs (Mohebifar et al., 2016). Previous studies showed that dimensions affect the service quality toward patient satisfaction (Mulia, 2017; Hidayah et al., 2019; Lely \& Suryati, 2018).

Poasia community health center is one of the community health centers in Kendari City, located in the Poasia District. Services factor provided by the Poasia community health center is considered necessary by patients; thereby, it provides the best service to patients and finds out whether the quality of services provided has met patient expectations. Previous research has been conducted at another community health center in Kendari City but in a different sub-district (Fristiohady et al., 2020). Therefore, this study aims to determine the satisfaction of outpatient for pharmacy services at the Poasia community health center. To measure the patient's expectation toward the Poasia community health center's services, the SERVQUAL model was used. The SERVQUAL is a multi-dimensional research instrument used to measure the patient's expectations of services and five dimensions used (Ko \& Chou, 2020). This research was conducted at the Poasia community health center, Kendari, to obtain the dimension that can be improved for further quality of patients' pharmaceutical service, specifically outpatients.

\section{MATERIALS AND METHODS}

In this study, the researcher's problem is quality service towards outpatient satisfaction patients at the Poasia community health center, Kendari. The research uses quantitative methods with outpatients as the subject. It was conducted for three months (November 2019 to January 2020). The population of the population is 1,300 patients. Due to the relatively large population, taking a sample to the patient, a total of 33 patients conducted Consecutive Sampling, is random sampling qualified 
inclusion until the required number of samples is met (Sastroasmoro \& Ismael, 2011). The study used consecutive random sampling because of the researchers' limited time and resources to research non-permanent populations every day.

Data collection techniques by distributing questionnaires or questions in writing to respondents to provide their opinions. For the statement of the indicators of measurement of the variables studied. The instruments were arranged according to the studied variables, accompanied by instructions on how to fill them. Then the data is processed using data analysis techniques in this research viz.

\section{Gap analysis}

The level of patient satisfaction is explained by using gap analysis. This analysis compares the mean between expectation and reality received by the patient from the service dimension, particularly reliability, responsiveness, assurance, empathy, and tangibles. The highest satisfaction occurs if the reality exceeds expectations (Zun et al., 2018), when the service provided is maximum (4) while the expectation is minimal (1) so that a score of $4-1=3$. Conversely, the lowest satisfaction occurs when the service provided is far below expectations, namely when the service provided is minimal (1) while the expectation is maximum (4), so a score of $1-4=-3$ is obtained. The satisfaction range is -3 to 3 so that an interval can be obtained using the formula (Mulyono, 1991):

$$
\begin{aligned}
\text { Interval } & =(\text { highest score-lowest score }) / \text { number of groups } \\
& =(3-(-3)) / 4 \\
& =1.5
\end{aligned}
$$

From the interval calculation, the gap classification is obtained as shown in Table I.

Table I. Classification of gaps (Djunaidi et al., 2006)

\begin{tabular}{ccc}
\hline Interval & Classification & Satisfaction Level \\
\hline-3 to -1.5 & Very negative & $\begin{array}{c}\text { Very dissatisfied with } \\
\text { expectations } \\
\text { Not satisfied with } \\
\text { expectations }\end{array}$ \\
\hline
\end{tabular}

\begin{tabular}{ccc}
\hline 0 to 1.5 & Positive & $\begin{array}{c}\text { More satisfied with } \\
\text { expectations } \\
\text { Very more satisfied } \\
\text { appeal expectations }\end{array}$ \\
\hline
\end{tabular}

\section{Test data normality}

Data normality test is carried out by statistical analysis. This test is carried out by inputting each statement's average reality and expectations in the questionnaire. This test is used to determine whether the data used is normally distributed or not to determine the next statistical test.

The test used to determine whether the data is normally distributed is to use Kolmogorov-Smirnov for large samples (more than 50 respondents) or Shapiro-Wilk for small samples (less than 50 respondents). If the significance value $>0.05$, the data is normally distributed (parametric data) and analyzed by paired t-test. Meanwhile, if the significance value $<0.05$, the data is not normally distributed (non-parametric data) and analyzed using the Wilcoxon test (Ghasemi \& Zahediasl, 2012).

\section{Paired t-test}

This test is conducted to determine whether there are significant differences between the reality and expectations studied to determine whether $\mathrm{H}_{0}$ is rejected or accepted. If the results obtained are significant differences, then $\mathrm{H}_{0}$ is rejected, but if the differences occur are not significant, then $\mathrm{H}_{0}$ is accepted. A paired t-test is carried out if the two data compared are normally distributed or the Wilcoxon test, if at least one of the data compared, is not normally distributed as seen from the value of reality and expectations.

\section{RESULTS AND DISCUSSION}

Poasia community health center is located in the Poasia district of Kendari, about $9 \mathrm{~km}$ from the Capital of the Province, as shown in Figure 1. The borders of the community health center, as follows: 
1. Kendari bay borders the north side

2. Abeli sub-district borders the east side.

3. Moramo sub-district borders the south side.

4. Kambu sub-district borders the west side.

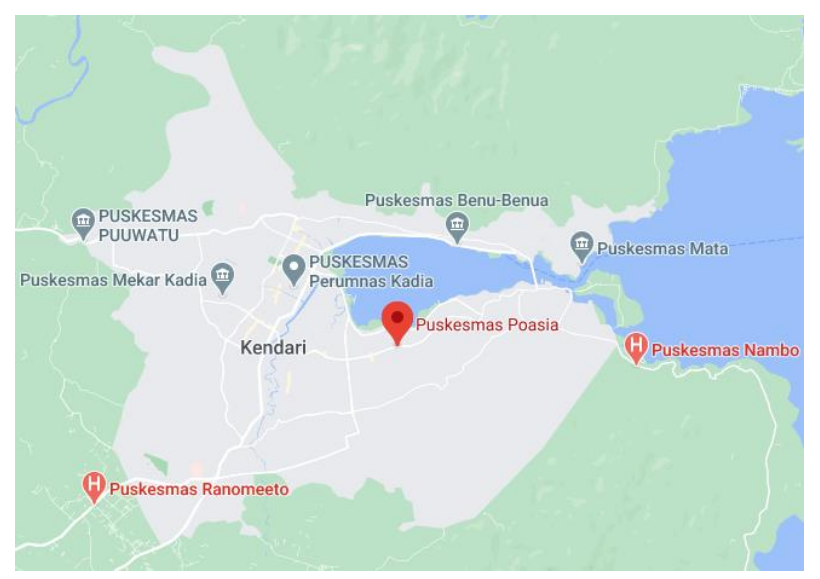

Figure 1. Poasia community health center location on the map of Kendari City (https://www.google.com/maps/@$3.9978063,122.5459704,17 \mathrm{z})$

\section{Gap analysis}

A gap analysis was obtained from the questionnaire results that were answered by 33 outpatients as respondents. The question items, the value of reality, expectations, and the gap analysis obtained are presented in Table II, with the largest gap shown in the question with the tangible dimension, while the smallest gap is shown by the responsiveness dimension. Analysis of each dimension based from the largest to the smallest gap of all five dimensions described as follows:

\section{Tangible}

Tangible is the patient's response to physical evidence provided by the health center pharmacy. In Table II, the smallest gap value is about the place of service, and the provision of adequate drug information is -0.88 , and the biggest regarding the neat appearance of the pharmacy staff is $-0.39(n=5)$. It means that patients are less satisfied with the services provided from the tangible dimension.

\section{Reliability}

Reliability shows the ability of pharmacies to carry out services that are reliable and trustworthy. In Table II, the smallest gap value of prescription services that are easy and straightforward is -0.69 , and the biggest one regarding the quality of drug packaging received in good condition is $-0.39(n=4)$. It means that patients are not satisfied with the services provided by the reliability dimension.

\section{Responsiveness}

Responsiveness is the patient's response to the pharmacy staff's willingness to help patients and provide services responsively. Table II shows that the pharmacy staff's smallest gap value immediately prepares the drug when receiving a prescription is -0.69 , and the biggest one about the pharmacy staff is not confused with the patient is 0.3 $(n=4)$. It means patients are less satisfied with the services provided, and in item 4, patients are quite satisfied with the services provided from the responsiveness dimension.

\section{Assurance}

Assurance is the patient's response to the pharmacist's knowledge and courtesy to feel confident and trusts when buying drugs. In Table II, the value gap is the smallest of the drug delivered to the patient is in good condition is -0.84 , and the greatest of the staff's pharmacies to prepare medications correctly and accurately is $-0.39(n=4)$. It means that patients are less satisfied with the services provided by the assurance dimension.

\section{Empathy}

Empathy is the patient's response to the personal attention given by the pharmacy staff. Table II shows that the pharmacy staff's smallest gap value paying attention to patients is -0.63 , and the biggest regarding pharmacy staff listening to patient complaints and questions patiently is $-0.39(n=5)$. It means patients are less satisfied with the services provided from the empathy dimension. 
Table II. Gap analysis at the Pharmacy of Poasia community health center

\begin{tabular}{|c|c|c|c|c|}
\hline Dimension & $\begin{array}{l}\text { Question } \\
\end{array}$ & Reality & Expectation & $\Sigma \mathrm{GAP}^{*}$ \\
\hline \multirow[t]{6}{*}{ Tangible } & 1. The neatness and cleanliness of the waiting room & 3.54 & 4.33 & -0.79 \\
\hline & 2. There are facilities such as AC, TV or comfortable magazines & 3.39 & 4.21 & -0.82 \\
\hline & 3. Place of adequate delivery of drugs & 3.82 & 4.30 & -0.48 \\
\hline & 4. Place of service and provision of adequate drug information & 3.73 & 4.61 & -0.88 \\
\hline & 5. The neat appearance of the pharmacy staff & 3.61 & 4.00 & -0.39 \\
\hline & $\begin{array}{c}\text { Average } \\
\end{array}$ & 3.61 & 4.29 & -0.68 \\
\hline \multirow[t]{5}{*}{ Reliability } & 6. The recipe service is easy and straightforward & 3.58 & 4.27 & -0.69 \\
\hline & 7. Prescription drugs are always available in Pharmacy & 3.82 & 4.12 & -0.3 \\
\hline & 8. Delivery of medication always matches the prescribed queue number & 3.67 & 4.09 & -0.42 \\
\hline & 9. The quality of the drug packaging received is in good condition & 3.61 & 3.73 & -0.12 \\
\hline & Average & 3.67 & 4.05 & -0.38 \\
\hline \multirow[t]{5}{*}{ Responsiveness } & $\begin{array}{l}\text { 10. Pharmacy officials immediately prepare the medicine when receiving a } \\
\text { prescription }\end{array}$ & 3.58 & 4.27 & -0.69 \\
\hline & 11. Pharmacy officials respond to patient problems & 3.73 & 4.12 & -0.39 \\
\hline & $\begin{array}{l}\text { 12. Drug handlers of drug delivery immediately provide information on } \\
\text { how to use, the dosage of use, side effects of drugs }\end{array}$ & 3.76 & 4.09 & -0.33 \\
\hline & 13. Pharmacy officials are not confused about the patient & 4.03 & 3.73 & 0.3 \\
\hline & Average & 3.77 & 4.05 & -0.28 \\
\hline \multirow[t]{5}{*}{ Assurance } & 14. The appearance and knowledge of the pharmacy staff is convincing & 3.79 & 4.21 & -0.42 \\
\hline & 15. Pharmacy officials prepare medicines correctly and thoroughly & 3.70 & 4.09 & -0.39 \\
\hline & $\begin{array}{l}\text { 16. Pharmacy officials again match prescription numbers and names of } \\
\text { patients when delivering drugs }\end{array}$ & 3.48 & 3.97 & -0.49 \\
\hline & 17. The medicine that was handed over to the patient was in good condition & 3.34 & 4.18 & -0.84 \\
\hline & Average & 3.57 & 4.11 & -0.54 \\
\hline \multirow[t]{6}{*}{ Empathy } & 18. Pharmacy officials provide services with polite and friendly & 3.82 & 3.91 & -0.09 \\
\hline & 19. Pharmacy staff listen to patient complaints and questions patiently & 3.97 & 4.18 & -0.21 \\
\hline & 20. Pharmacy officials pay attention to patients & 3.76 & 4.39 & -0.63 \\
\hline & $\begin{array}{l}\text { 21. Pharmacy officials provide the same service without differentiating } \\
\text { patients }\end{array}$ & 3.76 & 4.15 & -0.39 \\
\hline & 22. The presence of pharmacists in the community health center pharmacy & 3.97 & 4.33 & -0.36 \\
\hline & $\begin{array}{c}\text { Average } \\
\end{array}$ & 3.85 & 4.19 & -0.34 \\
\hline
\end{tabular}

* $\Sigma \mathrm{GAP}=$ Reality - Expectation

Based on Table II, it can be seen that the average value of the gap in the Poasia community health center's pharmacy, amounting to -0.44 . Meanwhile, from the value of the gap, the lowest gap value in the pharmacy center of Poasia is the place of service and the provision of inadequate drug information of -0.88 .

\section{Cartesian diagram}

A cartesian diagram of the value between reality and expectation at the Poasia community health center is presented in Figure 2. Of the 22 items, there are nine assessment items that are in quadrant I, five in quadrant II, four in quadrant III, and four in quadrant IV. The highest expectation value is shown in items number 6 and 10 with 4.27, while for the highest reality value is shown in item number 9 with 3.61 .

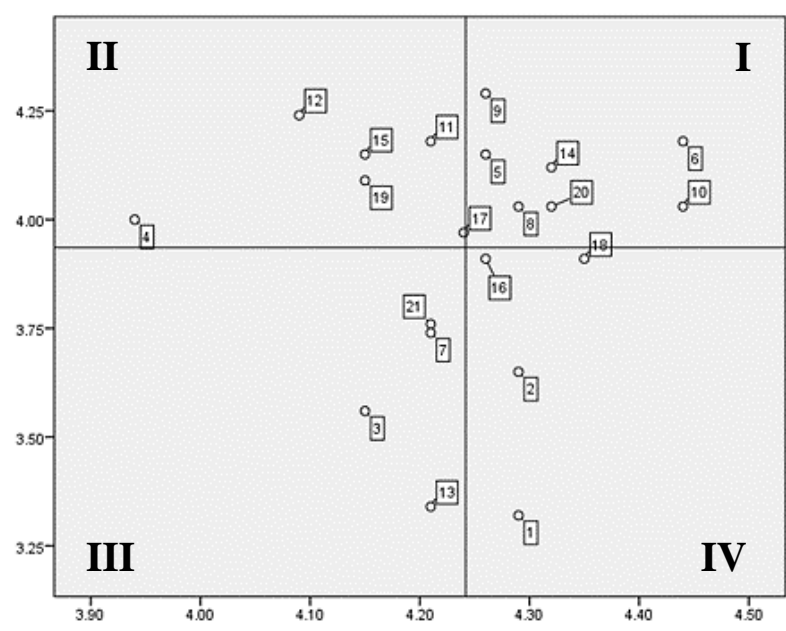

Figure 2. Cartesian diagram of the value between reality $(y)$ and expectation $(x)$ at the Poasia community health center

\section{Quadrant I}

The quadrant I items are assessments from questionnaires number 5, 6, 8, 9, 10, 14, 17, 20, and 22, where the most assessment is obtained from the dimension of reliability (three out of four). If seen from 
the patient's interests, the service is at a high level in this position. However, if seen from the reality, the patient feels a low level, the pharmacist is responsive to the patient's problem, the pharmacist provides the drug immediately with drug information, the pharmacist prepares the medicine correctly and thoroughly, the pharmacy staff listens to the patient complaints and questions, the medicine submitted is in good condition and demands improvement. The items included in this quadrant are places of service, and the supply of inadequate drug information is considered essential by patients because the reality received by patients does not match what they expect so that it still disappoints the patient.

\section{Quadrant II}

Quadrant II items are assessments of questionnaires number $4,11,12,15$, and 19, where no assessment of the reliability dimension falls into this category. This quadrant is shown about what needs to be maintained because the level of implementation of the service factor is in line with expectations and reality and attract patients to use it, specifically: the neat appearance of the pharmacy staff, prescription service is convenient and straightforward, the matches of drug delivery and according to queue numbers, drug in good quality, the pharmacy staff immediately prepares the drug when receiving a prescription, the appearance and knowledge of the pharmacy staff convincing, the pharmacy staff pays attention to the patient. So that patients feel satisfied and deserve to be maintained.

\section{Quadrant III}

Quadrant III items are assessments of questionnaires number $3,7,13$, and 21 , where no assessment of the assurance dimension falls into this category. This quadrant shows services that are still considered less important for patients, but when viewed from patient satisfaction level is not good. The items included in this quadrant are inadequate drug delivery, prescription drugs are always in the pharmacy, the pharmacy staff is not confused about the patient, the pharmacy staff provides the same service to all patients. Even though it is considered less important by the patient, its implementation is relatively low, so if the main priority has been improved, this low priority can be done.

\section{Quadrant IV}

Quadrant IV items are an assessment of questionnaires number $1,2,16$, and 18, where there is no assessment of the dimensions of reliability and responsiveness which fall into this category. It was shown the matter which was considered excessive by the patient because the patient considered the service not very important. Nevertheless, the implementation has been done well. The items included in this quadrant are the neatness and cleanliness of the waiting room, comfortable waiting room facilities, double-check the patient, and the prescription. It means that this item does not need to be the priority of the community health center.

\section{Data normality test}

Data normality testing was conducted using the Kolmogorov-Smirnov test as shown in Table III. The analysis results produce significance values $>0.05$, then the data can be normally distributed and can be continued with the paired t-test.

Table III. Data normality test

\begin{tabular}{ll}
\hline \multicolumn{2}{c}{ Sig. } \\
\hline 0.000 & Data is normally distributed. \\
\hline
\end{tabular}

\section{Paired t-test}

A paired t-test is an analysis involving two measurements on the subject of an influence. Based on the results contained in the $t$-test, the mean value at the pharmacy is -0.225 , as presented in Table IV. It means the satisfaction expected by the patient is less than the desired expectations so that the satisfaction received by the patient is still lacking; the reliability of the pharmacy staff 
is still unsatisfactory; the responsiveness of the pharmacist to the patients is still lacking except that the pharmacist is not confused with the patient; the assurance from the pharmacist to the patient regarding the information from the patient was still not satisfied; patients are still not satisfied with the attention given by the pharmacy staff due to crowded patients.

According to Table IV, it is known that based on the statistical calculation of paired t-test results obtained, there are differences in the average rating of respondents in assessing the quality of servants with a significant value of 0.000 . Based on statistical calculations with this $\mathrm{t}-$ test, it was also obtained that there was a gap between the expected service and the services provided by Pharmacy of Poasia community health center for outpatients with a mean value of -0.225 .

Table IV. Paired t-test

\begin{tabular}{lll}
\hline \multicolumn{2}{c}{ Sig. } & Mean \\
\hline 0.000 & -0.225 & \\
\hline
\end{tabular}

\section{CONCLUSION}

There are differences in respondents' average ratings in assessing the quality of servants with a significant value of 0.000 from the statistical calculation of paired t-test results. Based on these results, there is a gap between the expected service and the services provided for outpatients by the Poasia community health center's pharmacy, Kendari.

\section{ACKNOWLEDGMENT}

The authors thank the Faculty of Pharmacy of Universitas Halu Oleo, Kendari City Health Office, Poasia community health center, and Branch Manager of Ikatan Apoteker Indonesia (Indonesian Pharmacist Association) Kendari City, thus this research well conducted.

\section{REFERENCES}

Anderson, C. \& Sharma, R. (2020). Primary health care policy and vision for community pharmacy and pharmacists in England. Pharmacy Practice, 18(1), 1870. doi:10.18549/PharmPract.2020.1.1870

Bobbins, A.C., Burton, S., \& Fogarty, T.L. (2020). Different models of pharmaceutical services and care in primary healthcare clinics in the Eastern Cape, South Africa: Challenges and opportunities for pharmacy practice. African Journal of Primary Health Care and Family Medicine, 12(1), 2323. doi:10.4102/phcfm.v12i1.2323

Chusna, N., Fetriana, T., \& Adawiyah, R. (2018). Tingkat Kepuasan Pasien terhadap Pelayanan Kefarmasian di Puskesmas Pahandut Kota Palangka Raya. Borneo Journal of Pharmacy, 1(2), 89-92. doi:10.33084/bjop.v1i2.379

Djunaidi, M., Setiawan, E., \& Hariyanto, T. (2006). Analisis Kepuasan Pelanggan Dengan Pendekatan Fuzzy Service Quality Dalam Upaya Peningkatan Kualitas Pelayanan. Jurnal Ilmiah Teknik Industri, 4(3), 139-146. doi:10.23917/jiti.v4i3.1563

Fristiohady, A., Fitrawan, L.O.M., Pemudi, Y.D., Ihsan, S., Ruslin, R., Bafadal, M., Nurwati, N., \& Ruslan, R. (2020). Analisis Kualitas Pelayanan terhadap Kepuasan Pasien Rawat Jalan di Puskesmas Puuwatu Kota Kendari menggunakan Metode SERVQUAL. Jurnal Surya Medika (JSM), 6(1), 6-12. doi:10.33084/jsm.v6i1.1442

Ghasemi, A. \& Zahediasl, S. (2012). Normality Tests for Statistical Analysis: A Guide for NonStatisticians. International Journal of Endocrinology and Metabolism, 10(2), 486-489. doi:10.5812/ijem.3505

Herman, M.J. \& Susyanty, A.L. (2012). An Analysis of Pharmacy Services by Pharmacist in Community Pharmacy, Buletin Penelitian Sistem Kesehatan, 15(3), 271-281.

Hidayah, M.R., Pratiwi, H., \& Nuryanti, N. (2019). Evaluasi Kepuasan Pasien Terhadap Pelayanan Oleh Apoteker di Ruang Farmasi Puskesmas Purwokerto Timur I. Acta Pharmaciae Indonesia : Acta Pharm Indo, 7(1), 111. doi:10.20884/1.api.2019.7.1.2364 
Ismana, M.F. (2015). Hubungan Antara Lima Dimensi Mutu Pelayanan Rawat Jalan Dengan Kepuasan Pasien. Jurnal Kesehatan, 6(2), 708717. doi:10.38165/jk.v6i2.151

Ko, C.H. \& Chou, C.M. (2020). Apply the SERVQUAL Instrument to Measure Service Quality for the Adaptation of ICT Technologies: A CaseStudy of Nursing Homes in Taiwan. Healthcare, 8(2), 108. doi:10.3390/healthcare8020108

Krieger, J. \& Higgins, D.L. (2002). Housing and Health: Time Again for Public Health Action. American Journal of Public Health, 92(5), 758-768. doi:10.2105/ajph.92.5.758

Kumar, S. \& Preetha, G.S. (2012). Health Promotion: An Effective Tool for Global Health. Indian Journal of Community Medicine, 37(1), 5-12. doi:10.4103/0970-0218.94009

Kuntoro, W. \& Istiono, W. (2017). Kepuasan Pasien Terhadap Kualitas Pelayanan di Tempat Pendaftaran Pasien Rawat Jalan Puskesmas Kretek Bantul Yogyakarta. Jurnal Kesehatan Vokasional, 2(1), 140-147. doi:10.22146/jkesvo.30327

Lely, M. \& Suryati, T. (2018). Persepsi Pasien Rawat Jalan Terhadap Kualitas Pelayanan Di Rumah Sakit. Buletin Penelitian Kesehatan, 46(4), 239-246. doi:10.22435/bpk.v46i4.33

Lewis, R.C. \& Booms, B.H. (1983). The marketing aspect of service quality. In Berry L., Shostack, G., \& Upah, G. (Eds.). Emerging Perspective on Service Marketing. Chicago, US: American Marketing Association.

Martínez-Mardones, F., Ahumada-Canale, A., GonzalezMachuca, L., \& Plaza-Plaza, J.C. (2020). Primary health care pharmacists and vision for community pharmacy and pharmacists in Chile. Pharmacy Practice, 18(3), 2142. doi:10.18549/PharmPract.2020.3.2142

Mayberry, R.M., Nicewander, D.A., Qin, H., \& Ballard, D.J. (2006). Improving quality and reducing inequities: a challenge in achieving best care. Proceedings (Baylor University. Medical Center), 19(2), 103-118. doi:10.1080/08998280.2006.11928138

Ministry of Health of the Republic of Indonesia. (2016). Peraturan Menteri Kesehatan No. 74 Tahun 2016 Tentang Standar Pelayanan Kefarmasian di puskesmas. Jakarta, Indonesia: Ministry of Health of the Republic of Indonesia

Mitchell, P.H. (2008). Defining Patient Safety and Quality Care. In Hughes, R.G. (Ed). Patient Safety and Quality: An Evidence-Based Handbook for Nurses. Rockville, US: Agency for Healthcare Research and Quality.

Mohebifar, R., Hasani, H., Barikani, A., \& Rafiei, S. (2016). Evaluating Service Quality from Patients' Perceptions: Application of Importanceperformance Analysis Method. Osong Public Health and Research Perspectives, 7(4), 233-238. doi:10.1016/j.phrp.2016.05.002

Mulia, D.S. (2017). Tingkat Kepuasan Pasien Umum Rawat Jalan terhadap Kualitas Pelayanan Instalasi Farmasi RSUD Dr. Doris Sylvanus Palangka Raya. Jurnal Surya Medika (JSM), 2(2), 40-48. doi:10.33084/jsm.v2i2.358

Mulyono, S. (1991). Statistika Untuk Ekonomi. Jakarta, Indonesia: Lembaga Penerbit Fakultas Ekonomi Universitas Indonesia.

Nadi, A., Shojaee, J., Abedi, G., Siamian, H., Abedini, E., \& Rostami, F. (2016). Patients' Expectations and Perceptions of Service Quality in the Selected Hospitals. Medical Archives, 70(2), 135139. doi:10.5455/medarh.2016.70.135-139

Sastroasmoro, S. \& Ismael, S. (2011). Dasar-dasar Metodologi Penelitian Klinis. Jakarta, Indonesia: Binarupa Aksara.

Wendimagegn, N.F. \& Bezuidenhout, M.C. (2019). Integrating promotive, preventive, and curative health care services at hospitals and health centers in Addis Ababa, Ethiopia. Journal of Multidisciplinary Healthcare, 12, 243255. doi:10.2147/JMDH.S193370

Widayati, M.Y., Tamtomo, D., \& Adriani, R.B. (2017). Factors Affecting Quality of Health Service and Patient Satisfaction in Community Health Centers in North Lampung, Sumatera. Journal of Health Policy and Management, 2(2), 165-175. doi:10.26911/thejhpm.2017.02.02.08

Zun, A.B., Ibrahim, M.I., \& Hamid, A.A. (2018). Level of Satisfaction on Service Quality Dimensions Based onSERVQUAL Model Among Patients Attending 1 Malaysia Clinic in Kota Bharu, Malaysia. Oman Medical Journal, 33(5), 416-422. doi:10.5001/omj.2018.76 